\title{
Peran Kelompok Masyarakat dalam Rehabilitasi Ekosistem Mangrove di Pesisir Kota Semarang
}

\author{
Nana Kariada Tri Martuti ${ }^{1}$ \\ Jurusan Biologi, Fakultas Matematika dan IImu Pengetahuan Alam \\ Universitas Negeri Semarang, Semarang, Indonesia
}

\section{Sri Mulyani Endang Susilowati}

Jurusan Biologi, Fakultas Matematika dan IImu Pengetahuan Alam

Universitas Negeri Semarang, Semarang, Indonesia

\section{Wahid Akhsin Budi Nur Sidiq}

Jurusan Geografi, Fakultas IImu Sosial

Universitas Negeri Semarang, Semarang, Indonesia

\section{Ditha Prasisca Mutiatari}

Magister IImu Lingkungan, Sekolah Pascasarjana

Universitas Diponegoro, Semarang, Indonesia

Artikel Masuk : 19 Februari 2018

Artikel Diterima : 25 Juli 2018

Tersedia Online : 31 Agustus 2018

\begin{abstract}
Abstrak: Kawasan pesisir Kota Semarang memiliki fungsi yang strategis bagi pengembangan perekonomian regional. Adanya perubahan tata guna lahan berdampak pada kerusakan dan penurunan kualitas lingkungan kawasan pesisir kota. Penurunan kualitas lingkungan tersebut dapat berpengaruh pada kualitas sosial-ekonomi masyarakatnya. Penelitian ini bertujuan untuk mengetahui peran masyarakat dalam pengelolaan lingkungan yang berkelanjutan di kawasan pesisir Kota Semarang. Penelitian dilaksanakan di kawasan pesisir dua kelurahan yaitu Tugurejo dan Mangunharjo. Pendekatan penelitian yang digunakan adalah deskriptif kualitatif untuk menggambarkan peran masyarakat dalam upaya rehabilitasi lingkungan pesisir di kedua lokasi. Pengambilan data melalui survei pendahuluan disertai dengan kajian citra satelit yang menunjukkan ekosistem yang sesuai dengan materi penelitian. Selanjutnya metode analisis interaktif Miles dan Hubberman digunakan dalam pengolahan data sekunder dan primer. Hasil penelitian menunjukkan bahwa masyarakat memiliki peran penting dalam pengelolaan dan perbaikan kualitas pesisir yang lebih efektif dan efisien di Kota Semarang, karena masyarakat setiap hari berinteraksi dengan lingkungan tersebut. Berbagai kegiatan yang telah dilakukan oleh kelompok masyarakat dalam mengelola dan merehabilitasi kualitas pesisir meliputi pembuatan alat pemecah ombak (APO) serta pembibitan dan penanaman mangrove.
\end{abstract}

Kata Kunci: ekosistem mangrove; kawasan pesisir; kelompok masyarakat; Kota Semarang; rehabilitasi

Korespondensi Penulis: Jurusan Biologi, Fakultas Matematika dan Ilmu Pengetahuan Alam Universitas Negeri Semarang, Semarang, Indonesia

Email: nanakariada@mail.unnes.ac.id 


\title{
101 Peran Kelompok Masyarakat dalam Rehabilitasi Ekosistem Mangrove di Pesisir Kota Semarang
}

\begin{abstract}
The coastal area of Semarang City has a strategic function for regional economic development. Due to land use change, the environmental quality of coastal area is damaged and declining. The environmental quality decline has affected the socio-economic quality of local community. This research aims to investigate the role of local community in sustainable environmental management in Semarang City coastal area. The study takes place in two kelurahans, namely Tugurejo and Mangunharjo, and applies a descriptive qualitative approach to figure out the local community role in the coastal environment rehabilitation. Data collection through a preliminary survey supported with a satellite imagery study covers up an appropriate ecosystem with the research substance. Then the following data analysis and interpretation uses Miles and Huberman interactive analysis method. The results show the significant role of the local community in coastal area quality management and improvement in Semarang City more effectively and efficiently. This relates to their active interactions in various communitybased programs including wave-breaking instrument building and mangrove nursery and planting.
\end{abstract}

Keywords: coastal area; community group; mangrove ecosystem; rehabilitation; Semarang City

\section{Pendahuluan}

Kawasan pesisir Kota Semarang memiliki fungsi yang strategis bagi pengembangan perekonomian regional. Hal ini dikarenakan kawasan pesisir merupakan lokasi bagi sarana dan prasarana pelabuhan, Pembangkit Listrik Tenaga Uap (PLTU), usaha perikanan budi daya dan tangkap, kawasan konservasi serta objek wisata bahari. Pemanfaatan lahan- di kawasan pesisir Kota Semarang, sebagian besar digunakan untuk tambak (1.526,31 ha), kawasan pemukiman (936,84 ha), lahan pertanian (470 ha), sarana pelabuhan (147 ha), objek wisata bahari (55,12 ha) dan kawasan industri serta pergudangan (493,49 ha) (Dinas Kelautan dan Perikanan Kota Semarang, 2015).

Konversi kawasan pesisir menjadi kawasan permukiman, industri, tambak ikan, dan udang merupakan penyebab utama rusaknya kawasan pesisir. Perubahan tata guna lahan pesisir tersebut dapat memengaruhi kondisi ekosistem pesisir, termasuk di antaranya ekosistem mangrove yang merupakan vegetasi khas di kawasan pesisir. Ekosistem mangrove hanya tersisa pada bagian tertentu yang sangat terisolasi atau ditanam di tepi tambak yang berbatasan dengan pantai atau sungai untuk mencegah terjadinya abrasi (Setyawan \& Winarno, 2006). Kerusakan pantai dan lahan mangrove di kawasan pesisir Kota Semarang mengakibatkan kualitas lingkungan kawasan pesisir menurun. Selanjutnya penurunan kualitas lingkungan akhirnya berdampak pada kualitas sosial-ekonomi masyarakatnya.

Kota Semarang memiliki panjang garis pantai sesuai dengan lekuk daratan sepanjang $36,63 \mathrm{~km}$ dengan luas daratan pesisir 9.111,28 ha dan luas perairan 10.048,80 ha. Wilayah Kota Semarang memiliki luas wilayah $373,70 \mathrm{~km} 2$ yang terbagi menjadi 16 Kecamatan, dan empat di antaranya berbatasan dengan laut yaitu Kecamatan Tugu 2.985,99 ha (31,78\%), Semarang Barat $2.247,97$ ha $(21,74 \%)$, Semarang Utara 1.168,94 ha $(10,97 \%)$, dan Kecamatan Genuk 2.708,38 ha (27,39\%) (BPS Kota Semarang, 2017).

Mangrove merupakan ekosistem pada wilayah intertidal dengan interaksi yang kuat antara perairan laut, payau, sungai dan terestrial. Interaksi ini menjadikan ekosistem mangrove mempunyai keanekaragaman hayati yang tinggi baik berupa flora maupun fauna (Martuti, 2013). Eksploitasi kawasan mangrove yang terus-menerus dilakukan berpotensi mereduksi keanekaragaman spesies tumbuhan, yang memiliki peran dan fungsi utama secara ekologis dan potensial untuk dimanfaatkan secara sosial-ekonomi. Mengingat pentingnya fungsi ekosistem mangrove dalam menjaga keseimbangan kawasan pesisir, khususnya dalam menjaga keanekaragaman hayati, menyediakan habitat dan jasa ekosistem, maka sangat diperlukan upaya-upaya untuk melindunginya.

Untuk mempertahankan kelestarian hutan mangrove, suatu sistem pengelolaan kawasan pesisir perlu memperhatikan prinsip kesinambungan fungsi hutan mangrove 
eksisting. Ekosistem mangrove di kawasan pesisir yang terpelihara, serta didukung dengan kesadaran dan kesamaan persepsi berbagai pihak tentang pentingnya keberadaan eksosistem mangrove akan berdampak terhadap keberlanjutan kawasan pesisir.

Hasil kajian Ambariyanto \& Sugianto (2012) tentang pengembangan desa pesisir tangguh di Kota Semarang menunjukkan bahwa kawasan pesisir kota ini termasuk dalam kategori kerentanan rendah dan sedang. Berbagai upaya telah dilakukan oleh masyarakat untuk memperbaiki kawasan pesisir antara lain dengan penanaman mangrove, pemasangan alat pemecah ombak (APO), serta pemanfaatan mangrove sebagai destinasi ekowisata yang berkelanjutan. Sebagaimana disampaikan oleh Basyuni et al., (2016) dalam penelitiannya di Desa Lubuk Kertang Kecamatan Brandan Barat, Kabupaten Langkat Sumatera Utara, peningkatan pengelolaan ekosistem hutan mangrove dapat dilakukan melalui kegiatan ekowisata dan interpretasi lingkungan dengan memperhatikan daya dukung wilayah tersebut.

Dalam hal ini, pelibatan masyarakat berkontribusi penting untuk menjaga serta melakukan rehabilitasi kawasan pesisir. Pelibatan tersebut meliputi persiapan program, implementasi maupun monitoring sehingga masyarakat merasa bertanggung jawab dalam rehabilitasi dan pemeliharaan lingkungan guna terciptanya lingkungan pesisir yang lestari. Namun, sinergi dan komunikasi yang baik antara pemerintah sebagai fasilitator dan masyarakat sebagai pelaku sangat diperlukan untuk mengefektifkan pelibatan masyarakat ini (Raharjo, Setiady, Zallesa, \& Putri, 2015). Sebenarnya penelitian tentang keberadaan dan fungsi ekosistem mangrove di pesisir Kota Semarang sudah banyak dilakukan, namun belum ada yang mengkaji tentang bagaimana peran masyarakat dalam mengelola kawasan pesisir Kota Semarang. Oleh karena itu, penelitian ini bertujuan untuk mengetahui bagaimana peran masyarakat dalam pengelolaan lingkungan yang berkelanjutan di kawasan pesisir Kota Semarang.

\section{Metode Penelitian}

Penelitian ini dilakukan di kawasan pesisir Kota Semarang yang meliputi Kelurahan Tugurejo dan Kelurahan Mangunharjo. Penelitian dilaksanakan pada bulan Maret-Agustus tahun 2017. Lokasi penelitian dapat dilihat pada Gambar 1.

\section{Rancangan Penelitian}

Pendekatan yang digunakan dalam penelitian ini mengunakan deskriptif kualitatif. Penelitian deksriptif kualitatif adalah penelitian tentang suatu kondisi dengan membuat deskripsi dan gambaran secara sistematis, faktual dan akurat mengenai fakta-fakta, sifat-sifat serta mengkaji hubungan antarfenomena yang diselidiki (Nazir, 2011). Jenis penelitian kualitatif yang dipilih dalam penelitian ini adalah studi kasus (Baxter \& Jack, 2008). Metode studi kasus secara inkuiri empiris dianggap dapat menemukan dan menggambarkan fenomena serta konteks peran serta yang telah dilakukan oleh masyarakat dalam upaya merehabilitasi ekosistem mangrove di Kelurahan Mangunahrjo dan Dukuh Tapak Kelurahan Tugurejo. Subjek penelitian adalah anggota masyarakat yang secara pribadi maupun berkelompok memiliki keterlibatan dalam upaya rehabilitasi pesisir.

Kegiatan penelitian ini diawali survei pandahuluan dengan metode observasi lapangan. Tahapan ini dilakukan untuk mendapatkan lokasi penelitian yang diharapkan dapat mewakili kondisi kawasan pesisir di Kota Semarang. Selain itu, kegiatan ini juga digunakan untuk mendata keberadaan kelompok lingkungan lokal yang secara langsung maupun tidak langsung berperan dalam pengelolaan kawasan pesisir yang akan diteliti. 


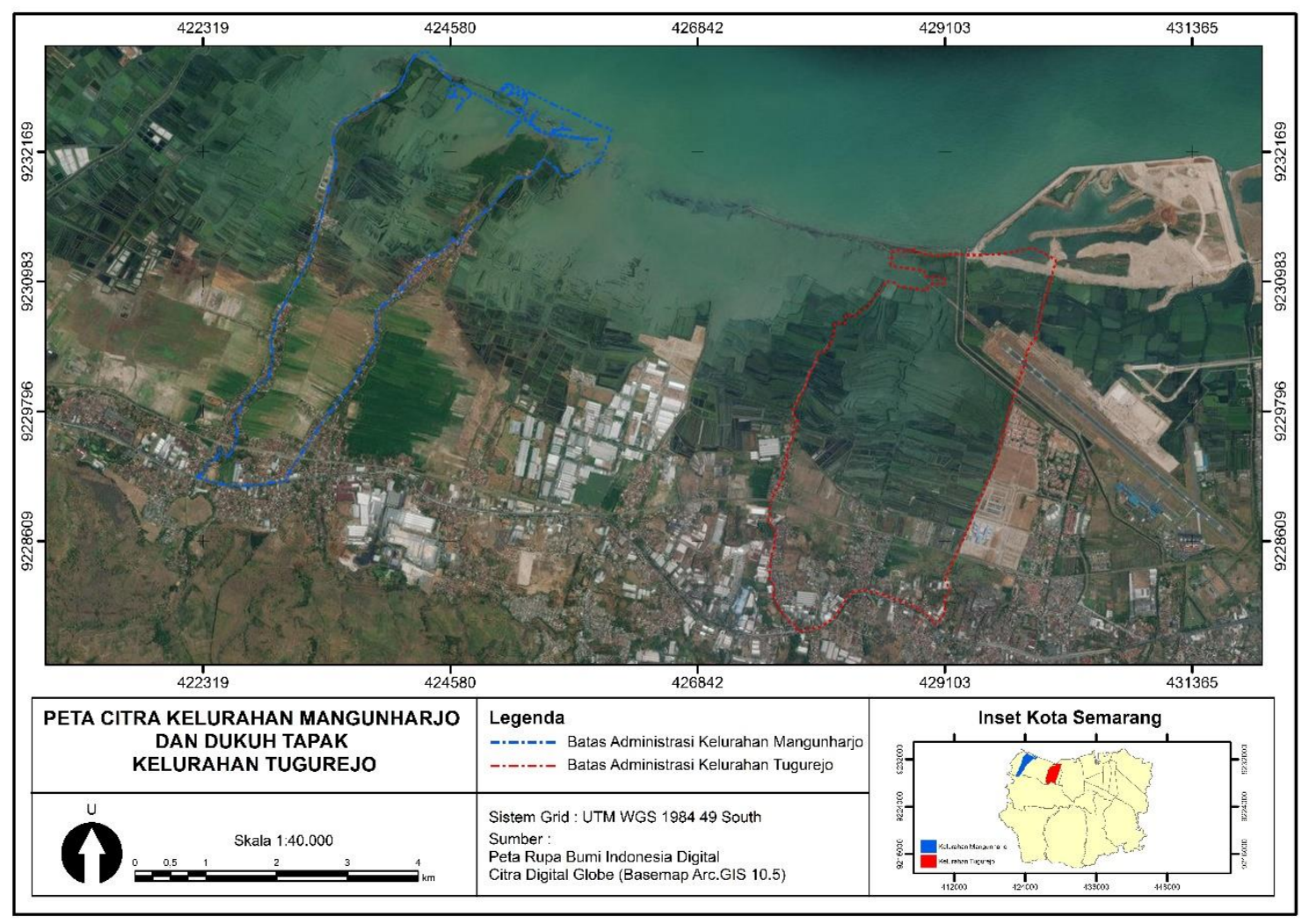

Sumber: Modifikasi dari Peta Rupa Bumi Indonesia Digital, 2001 dan Citra Resolusi Tinggi, 2016

\section{Gambar 1. Peta Lokasi Penelitian Kelurahan Mangunharjo dan Dusun Tapak Kelurahan Tugurejo}

\section{Teknik Pengumpulan dan Analisis Data}

Teknik pengumpulan data menggunakan metode observasi, wawancara dan Focus Group of Discussion (FGD). Hasil yang diperoleh dari survei pendahuluan beserta kajian citra satelit menunjukkan ekosistem yang sesuai dengan materi penelitian. Selanjutnya, pelaksanaan penelitian mencakup beberapa hal yang menjadi data dasar penelitian meliputi:

a. Data sekunder, meliputi hasil dokumentasi yang dimiliki oleh setiap wilayah yang sudah ditentukan (Kelurahan Tugurejo dan Kelurahan Mangunharjo), studi literatur, dan hasil penelitian sebelumnya (jurnal, makalah, dan informasi dari media masa);

b. Data primer, diperoleh dari FGD bersama kelompok lingkungan di pesisir Kota Semarang dan narasumber kunci untuk mendapatkan data kualitatif maupun data kuantitatif; dan

c. Penentuan ukuran kawasan yang akan diteliti sesuai dengan hasil kajian citra satelit yang sudah dipresentasikan. Adanya penentuan luas wilayah ini menentukan luasan pengambilan sampel beserta jumlah narasumber yang diambil datanya. Pemilihan narasumber dilakukan dengan mempertimbangkan beberapa hal berikut: (1) telah bertempat tinggal di wilayah Mangunharjo dan Tugurejo $>5$ tahun dan memiliki usia $>30$ tahun, sehingga dapat memberikan informasi sejarah konversi mangrove secara netral dan terbuka (Wijayanti \& Pratomo, 2016); dan (2) memiliki keterlibatan dalam kelompok peduli lingkungan.

Analisis data yang digunakan dalam penelitian ini menggunakan metode analisis interaktif (Miles et.al., 2014). Penerapan metode ini dilakukan dengan menelaah data terkait peran serta masyarakat dalam rehabilitasi ekosistem mangrove di pesisir Kota Semarang 
yang diperoleh dari berbagai sumber seperti wawancara, observasi, FGD, studi literatur dan berbagai sumber lainnya.

\section{Hasil dan Pembahasan}

\section{Peran Masyarakat dalam Rehabilitasi Kawasan pesisir Kota Semarang}

Berbagai upaya rehabilitasi kawasan pesisir telah dilakukan oleh berbagai elemen masyarakat, baik dari kelompok peduli lingkungan, perguruan tinggi, lembaga swadaya masyarakat (LSM), swasta, dan instansi pemerintah yang ada di Kota Semarang. Kepedulian terhadap rehabilitasi tersebut di antaranya mencakup penanaman mangrove, pembuatan APO, dan breakwateryang didanai oleh Badan Lingkungan Hidup (BLH) Kota Semarang dan Provinsi Jawa Tengah, Dinas Kelautan dan Perikanan Kota Semarang dan Provinsi Jawa Tengah, Universitas Diponegoro (UNDIP), Universitas Negeri Semarang (UNNES), Mercy Corps Indonesia, dan Djarum Foundation.

Keterlibatan berbagai pemangku kepentingan (multi stakeholder) dalam upaya rehabilitasi kawasan pesisir di Kota Semarang menunjukkan sebuah model kemitraan penta helix, meliputi unsur akademisi, bisnis, pemerintah, masyarakat, dan LSM. Kemitraan penta helix tersebut dapat didefinisikan sebagai model rehabilitasi pesisir untuk mendorong pemulihan dan perbaikan fungsi ekosistem pesisir yang seimbang melalui kolaborasi dan kemitraan yang menguntungkan. Pendekatan program dengan model kemitraan multi stakeholder meningkatkan potensi kepastian (legalitas) dan keberhasilan program (Soesilowati et al., 2017). Gambar 2 memperlihatkan model kemitraan penta helix sebagai upaya rehabilitasi kawasan pesisir di Kota Semarang yang diadopsi dari Halibas, Sibayan, \& Maata (2017) dan Prabantarikso et.al. (2018).

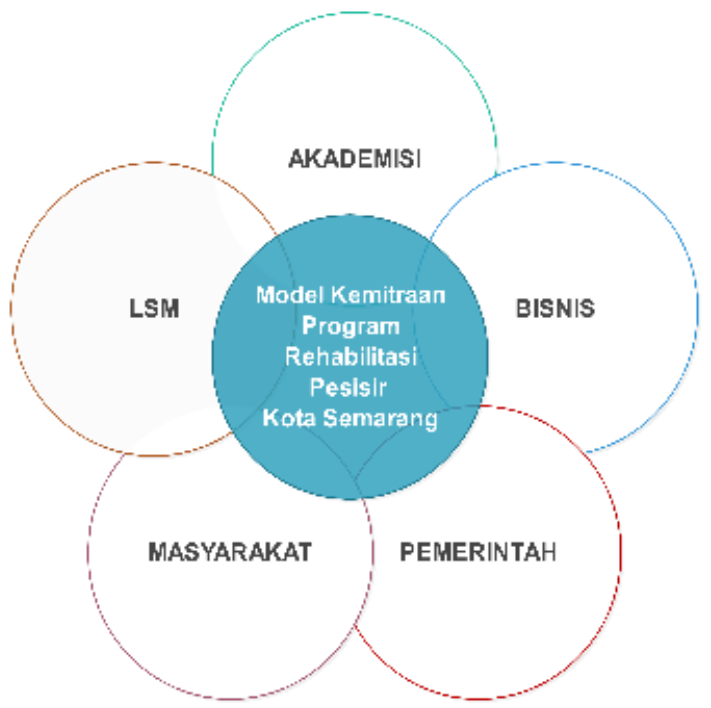

Sumber: Analisis Penulis, 2018

Gambar 2. Model Kemitraan Penta Helixdalam Program Rehabilitasi Pesisir di Kota Semarang

Dalam kolaborasi penta helix di Gambar 2 tersebut setiap pemangku kepentingan memiliki peran berdasarkan potensi dan kewenangan yang dimiliki. Peran dan kewenengan tersebut yaitu: (1) akademisi dengan modal pengetahuan dan keahlian diposisikan dalam konsultasi program dan pemberdayaan masyarakat; (2) bisnis atau private sector dengan alokasi pendanaan corporate social responsibility (CSR); (3) pemerintah sebagai pembuat 
kebijakan, sumber pembiayaan untuk infrastruktur dan transfer teknologi, pelaksana fungsi stimulan dan koordinasi; (4) masyarakat sebagai aktor kunci dan akselerator keberhasilan program; dan (5) LSM terlibat dalam penyediaan sumber pembiayaan alternatif, pendampingan, dan pengkondisian masyarakat.

Peraturan Presiden Republik Indonesia Nomor 121 Tahun 2012 tentang Rehabilitasi Kawasan pesisir dan Pulau-Pulau Kecil mendefinisikan rehabilitasi sebagai proses pemulihan dan perbaikan kondisi ekosistem atau populasi yang telah rusak walaupun hasilnya dapat berbeda dari kondisi semula. Pelaksanaan rehabilitasi pesisir meliputi pengayaan sumber daya hayati, perbaikan habitat, perlindungan spesies biota, dan pengelolaan yang ramah lingkungan. Merujuk peraturan tersebut, peran serta masyarakat dalam pelaksanaan rehabilitasi dapat disajikan Tabel 1.

Tabel 1. Keterlibatan Masyarakat dalam Program Rehabilitasi Pesisir di Kota Semarang

\begin{tabular}{|c|c|c|c|c|c|c|c|}
\hline \multirow{2}{*}{$\begin{array}{l}\text { Pelaksanaan } \\
\text { Rehabilitasi }\end{array}$} & \multirow{2}{*}{ Kegiatan } & \multirow{2}{*}{ Lokasi } & \multicolumn{5}{|c|}{ Keterlibatan } \\
\hline & & & $\mathbf{A}$ & B & $\mathbf{P}$ & $\mathbf{M}$ & $\mathbf{L}$ \\
\hline $\begin{array}{l}\text { Pengayaan } \\
\text { Sumberdaya }\end{array}$ & Penanaman Mangrove & $\begin{array}{l}\text { Tugurejo dan } \\
\text { Mangunharjo }\end{array}$ & $\sqrt{ }$ & $\sqrt{ }$ & $\sqrt{ }$ & $\sqrt{ }$ & $\sqrt{ }$ \\
\hline Hayati & Pengadaan benih mangrove & $\begin{array}{l}\text { Tugurejo dan } \\
\text { Mangunharjo }\end{array}$ & $\sqrt{ }$ & $\sqrt{ }$ & $\sqrt{ }$ & $\sqrt{ }$ & $\sqrt{ }$ \\
\hline $\begin{array}{l}\text { Perbaikan } \\
\text { habitat }\end{array}$ & $\begin{array}{l}\text { Pembuatan sabuk pantai dari } \\
\text { beton }\end{array}$ & Mangunharjo & - & - & $\sqrt{ }$ & $\sqrt{ }$ & - \\
\hline $\begin{array}{l}\text { Perlindungan } \\
\text { spesies biota }\end{array}$ & $\begin{array}{l}\text { Penyuluhan dan penyadaran } \\
\text { melalui kegiatan ekowisata }\end{array}$ & $\begin{array}{l}\text { Tugurejo dan } \\
\text { Mangunharjo }\end{array}$ & $\sqrt{ }$ & - & $\sqrt{ }$ & $\sqrt{ }$ & $\sqrt{ }$ \\
\hline $\begin{array}{l}\text { Pengelolaan } \\
\text { ramah } \\
\text { Lingkungan }\end{array}$ & Pembuatan APO dari ban bekas & Tugurejo & $\sqrt{ }$ & $\sqrt{ }$ & $\sqrt{ }$ & $\sqrt{ }$ & $\sqrt{ }$ \\
\hline
\end{tabular}

Keterangan: $\mathrm{A}=$ Akademisi; $\mathrm{B}=$ Bisnis; $\mathrm{P}=$ Pemerintah; $\mathrm{M}=$ Masyarakat $\mathrm{L}=\mathrm{LSM} ; \sqrt{ })=$ terlibat; $(-)=$ tidak terlibat

Sumber: Analisis Penulis, 2018

Upaya rehabilitasi kawasan pesisir yang telah dilakukan oleh masyarakat di Kelurahan Tugurejo dan Kelurahan Mangunharjo dapat dijabarkan pada uraian berikut.

\section{Kelurahan Tugurejo}

Dalam upaya pengelolaan lingkungan pesisir, masyarakat Dukuh Tapak Kelurahan Tugurejo telah melakukan rehabilitasi lingkungan terkait dengan perbaikan wilayahnya. Sejak tahun 2003, melalui Kelompok Prenjak warga mulai merintis upaya-upaya dalam pengelolaan lingkungan. Kegiatan-kegiatan yang dilakukan meliputi penanaman mangrove, pembuatan APO hingga pelibatan seluruh elemen masyarakat seperti petani tambak dan nelayan untuk mencetuskan Dukuh Tapak sebagai daerah konservasi dan ekoeduwisata mangrove.

Masyarakat setempat melakukan rehabilitasi kawasan pesisir dengan menanam mangrove dan mengurangi dampak abrasi dengan memasang ban bekas yang disusun secara rapi serta diisi sedimen lumpur pada bagian dalamnya, yang oleh masyarakat setempat disebut sebagai APO. Upaya yang mereka lakukan ternyata cukup efektif. Hal ini dibuktikan dengan kondisi ban bekas yang masih terpasang baik sejak tahun 2006, meskipun masyarakat harus melakukan pengisian lumpur sebagai proses perawatan terhadap konstruksi ini. Keberadaan APO melindungi lahan tambak di sekitarnya dari abrasi yang mengikis daratan Pulau Tirang. APO juga dapat melindungi tanaman mangrove dari 
hempasan gelombang dan angin kencang (Hartati et.al, 2016). Upaya ini sejalan dengan hasil studi Yulistiyanto (2009) yang menyimpulkan bahwa perlindungan dan pengamanan pantai dapat dilakukan dengan reboisasi mangrove sebagai bentuk perlindungan alami. Namun, reboisasi mangrove memerlukan dukungan struktur APO yang baik, sehingga tanaman mangrove dapat tumbuh cukup besar dan mampu menahan gelombang.

Pembangunan APO banyak memberikan dampak positif sehingga masyarakat dengan sadar melakukan perawatan secara mandiri agar manfaat yang mereka terima dapat dirasakan dalam jangka waktu yang lama (Hartati et al., 2016). Pemilihan bahan baku APO dari bambu dan ban bekas dilakukan karena pertimbangan dasar pantai yang berupa lumpur berpasir. APO tipe bambu dan ban mampu melindungi tambak dari gelombang dan pasang tinggi. Pembangunan APO tipe ini memungkinkan pemulihan habitat mangrove yang membutuhkan pendangkalan sedimen halus dan tingkat sedimentasi yang lebih besar, sehingga pemulihan kerusakan pesisir dapat dilakukan lebih cepat (Hartati et al., 2016).

Selama proses pembangunan APO selalu disertai dengan monitoring yang bertujuan untuk memantau dan mengambil pembelajaran dari kegiatan tersebut (Hartati et al., 2016). Desain pembangunan APO berbahan baku ban bekas yang dibuat di Kelurahan Tugurejo merupakan pengembangan APO yang diawali oleh Friend of the Earth (FoE) Jepang di Kecamatan Tugu, kemudian ditindaklanjuti oleh Mercy Corps Indonesia (2015-2016). Gambar 3 menunjukkan pemasangan APO di Dukuh Tapak Kelurahan Tugurejo.

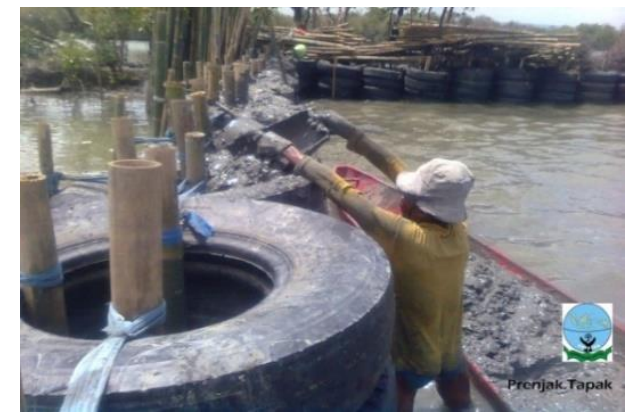

Sumber: Dokumentasi Penulis, 2018

\section{Gambar 3. Pemasangan APO dari Ban Bekas di Dukuh Tapak Kelurahan Tugurejo}

Upaya yang dilakukan oleh masyarakat Dukuh Tapak Kelurahan Tugurejo mengundang perhatian lembaga dari luar negeri seperti FoE Jepang dan Mercy Corps Indonesia untuk melakukan peningkatan pengetahuan kelompok masyarakat, penanaman mangrove, dan pembuatan APO. Selain itu, pada tahun 2010 Dinas Kelautan dan Perikanan dan Badan Lingkungan Hidup Kota Semarang ikut terlibat memberikan kegiatan kepada masyarakat setempat.

Kondisi mangrove di Dukuh Tapak tergolong cukup baik jika dibandingkan dengan daerah lain di sekitarnya. Hasil laporan Dinas Kelautan dan Perikanan Kota Semarang (2015) menunjukkan bahwa rata-rata kerapatan terendah mangrove kategori pohon di Dukuh Tapak Kelurahan Tugurejo 2.500 ind/ha. Sejak tahun 2000 secara masif dilakukan kegiatan penanaman mangrove baik oleh masyarakat setempat maupun lembaga-lembaga pemerintah, swasta, LSM, pelajar, dan mahasiswa. Terkait dengan program rehabilitasi kawasan pesisir, sejak tahun 2013 Mercy Corps Indonesia bekerjasama dengan Kelompok Prenjak telah malakukan pembibitan mangrove yang terdiri atas Rhizophora sp, Brugueira gymnoriza dan Avicennia marina sebanyak 40.500 batang, dengan rincian 10.000 dalam bentuk propagul, dan 30.500 bibit dalam polybag (Mercy Corps Indonesia, 2016).

Setiap pembangunan di kawasan pesisir Dukuh Tapak Kelurahan Tugurejo ini masyarakat dilibatkan secara aktif dalam perencanaan, pelaksanaan, dan monitoring. 
Sebagai bentuk kepedulian masyarakat terhadap lingkungan wilayahnya, dibentuklah beberapa kelompok masyarakat yang dapat berperan serta di dalam kegiatan rehabilitasi kawasan pesisir. Kelompok tersebut selanjutnya dibagi menjadi:

1. Perkumpulan Pemuda Cinta Alam Tapak atau Prenjak

Perkumpulan Prenjak ini aktif di bidang lingkungan pesisir yang diketuai oleh Muhammad Arifin. Prenjak menjadi perkumpulan yang mendorong pemberdayaan masyarakat di Dukuh Tapak sekaligus menjadi motor untuk perkembangan Dukuh Tapak dan perwujudan daerah konservasi di kawasan pesisir Tugurejo.

2. Kelompok Petani Tambak (Sido Rukun)

Kelompok Sido Rukun beranggotakan masyarakat yang mengelola tambak di pesisir Dukuh Tapak dan diketuai oleh Achmadun. Kelompok Sido Rukun ini berperan dalam penanaman mangrove di bagian tambak. Pola penanaman dilakukan di galengan dan di dalam tambak (wanamina). Wanamina merupakan sistem pertambakan teknologi tradisional yang menggabungkan antara usaha perikanan dengan penanaman mangrove, yang diikuti dengan konsep pengenalan sistem pengelolaan dengan meminimalkan input dan mengurangi dampak terhadap lingkungan (Macintosh \& Ashton, 2002). Konsep wanamina di Dukuh Tapak dikembangkan untuk mendapatkan jalan keluar terbaik dalam pengembangan kawasan pesisir Kota Semarang.

3. Kelompok Wanita Pesisir Tapak "Putri Tirang"

Kelompok ini berisikan para wanita dan ibu-ibu Dukuh Tapak yang aktif dalam pengolahan hasil pesisir dari mulai hasil tangkap nelayan, hasil budi daya tambak, dan pengolahan makanan berbahan baku buah mangrove.

4. Pokdarwis Bina Tapak Lestari

Kelompok yang diketuai oleh Abdul Roviq ini bergerak di bidang ekoeduwisata mangrove. Kelompok Sadar Wisata (Pokdarwis) mengelola anggota kelompok dalam menyambut wisatawan yang hadir di wilayah Tapak untuk melakukan wisata mangrove. Keberadaan ekoeduwisata mangrove ini diharapakan dapat mengenalkan dan memberikan pendidikan kepada masyarakat tentang peran penting mangrove bagi kawasan pesisir. Sebagaimana disampaikan oleh Umam, Sudiyarto, \& Winarno (2015), ekoeduwisata mangrove menjadi sarana konservasi mangrove di kawasan pesisir. Hal ini dapat dilakukan dengan program gerakan menanam bibit mangrove yang dilakukan oleh wisatawan. Gerakan menanam ini dapat melestarikan hutan mangrove sekaligus menjaga ekologi pesisir pantai.

Kelompok-kelompok tersebut bertugas melakukan pola kerja sama dengan mengajak masyarakat setempat untuk menjaga dan mewujudkan Dukuh Tapak menjadi kawasan konservasi. Saat ini, Dukuh Tapak Kelurahan Tugurejo dikenal sebagai wilayah dengan ekoeduwisata mangrove yang menjadi tempat wisata pendidikan bagi anak-anak sekolah serta masyarakat umum. Sebagaimana disampaikan oleh Basyuni et al. (2016), ekowisata dapat meningkatkan pengelolaan ekosistem hutan mangrove serta dapat menjaga objek ekowisata mangrove dengan tetap memperhatikan daya dukung wilayah. Meningkatnya pengetahuan dan kepedulian masyarakat dalam menjaga kelestarian lingkungan pesisir menjadi aspek yang sangat penting. Mengingat kerusakan kawasan pesisir di Indonesia, sebagian besar disebabkan oleh adanya perilaku manusia yang merusak, selain karena faktor alam (Widayatun, 2011).

\section{Kelurahan Mangunharjo}

Kelurahan Mangunharjo merupakan kawasan pesisir di Kota Semarang yang memiliki 17 kelompok masyarakat, yang terdiri dari kelompok pengolah ikan, kelompok nelayan, kelompok budi daya, dan kelompok peduli lingkungan. Melalui kelompok-kelompok tersebut masyarakat melakukan upaya-upaya dan mencari jalan keluar dalam menghadapi masalah lingkungan di wilayahnya. Kelompok-kelompok masyarakat di Mangunharjo tidak hanya melakukan adaptasi untuk perbaikan ekonomi, tetapi juga melakukan adaptasi untuk perbaikan lingkungan. Kapasitas adaptasi menurut Sakuntaladewi \& Sylviani (2014) meliputi 
perbaikan lingkungan biofisik, variasi sumber penghasilan, ekstensifikasi lahan usaha, penerapan teknologi pertanian dan perikanan, penyesuaian jadwal kegiatan usaha dengan perkiraan musim, alih profesi tetap pada kegiatan lama dan berharap pada keuntungan, kuatnya kelembagaan masyarakat, bantuan atau program pembangunan desa, dan pendampingan yang intensif

Selama ini, kelompok masyarakat pesisir Mangunharjo melakukan upaya perbaikan lingkungan dengan menanam mangrove dan membuat sabuk pantai atau breakwater dari beton. Sebagaimana disampaikan oleh Hartati et al. (2016), pendekatan dalam perencanaan pembangunan perlindungan pantai buatan dapat dilakukan dengan: (a) mengurangi energi gelombang yang mengenai pantai dengan membangun pemecah gelombang lepas pantai (breakwater/APO); (b) memperkuat tepi pantai sehingga tahan terhadap gempuran gelombang dengan membangun revetment atau sea wall; (c) menambah suplai sedimen ke pantai dengan cara sand by passing atau beach nourishment; dan (d) melakukan penghijauan pantai dengan pohon bakau, api-api, atau nipah.

Beberapa kelompok masyarakat pesisir melakukan penanaman mangrove karena inisiatif sendiri, tetapi banyak juga yang melakukan penanaman karena dorongan (stimulan) dari pihak luar. Selain melakukan penanaman, kelompok-kelompok lingkungan tersebut juga melakukan pembibitan mangrove sebagai alternatif penghasilan. Pembibitan mangrove yang dikembangkan di Kelurahan Mangunharjo terdiri dari jenis Rhizophora sp dan Avicennia marina. Avicennia marina merupakan salah satu jenis mangrove yang termasuk tumbuhan pionir pada kawasan pesisir yang terlindungi, serta mempunyai kemampuan untuk tumbuh pada habitat pasang-surut yang mempunyai salinitas tinggi. Akar Avicennia marina sering membantu mengikat sedimen dan mempercepat proses pembentukan sedimentasi (Martuti, et.al, 2016). Selain berperan untuk menanggulangi abrasi, mangrove juga mempunyai peran sebagai tempat berpijah berbagai jenis ikan, udang, dan biota laut lainnya, menyerap logam, dan menjaga stok karbon yang tinggi, sehingga mempunyai peran yang baik untuk menjaga lingkungan (Martuti, et.al, 2017).

Pada awalnya, kelompok-kelompok peduli lingkungan melakukan penanaman mangrove karena inisiatif sendiri. Seiring dengan berjalannya waktu, penanaman mangrove juga dilakukan karena adanya berbagai stimulant program yang berasal dari instasi pemerintah, LSM, dan pergurunan tinggi. Adapun kelompok-kelompok peduli lingkungan yang terdapat di Kelurahan Mangunharjo adalah:

1. Biota Foundation

Kelompok yang aktif dalam pengelolaan kawasan pesisir ini dipimpin oleh Abdul Azis. Kelompok yang terbentuk atas inisitif masyarakat sendiri hadir sebagai upaya untuk terlibat aktif dalam menyelesaikan masalah lingkungan di pesisir Kelurahan Mangunharjo. Embrio Biota Foundation berawal sejak tahun 2006, karena sebelumnya telah memiliki nama Forum Masyarakat Pesisir (FORMASSI), kemudian berganti nama menjadi LSM LEPPAS, dan terakhir sesuai kesepakatan para pengurus dan anggota pada tahun 2011 berganti nama menjadi Biota Foundation. Sejumlah aktivitas lingkungan yang telah dilakukan oleh Biota Foundation antara lain penanaman mangrove, pembuatan sabuk pantai dari beton, serta pendampingan penanaman mangrove, penelitian, dan studi lingkungan. Menurut Ichsan \& Suleman (2018), sabuk pantai dibangun untuk melindungi kawasan pesisir dari serangan gelombang. Perlindungan sabuk pantai yang ada di lepas pantai dapat berfungsi untuk mengurangi energi gelombang yang sampai di perairan di belakang bangunan. Gambar 4 menunjukkan APO yang dibangun oleh Kelompok Biota Foundation. 


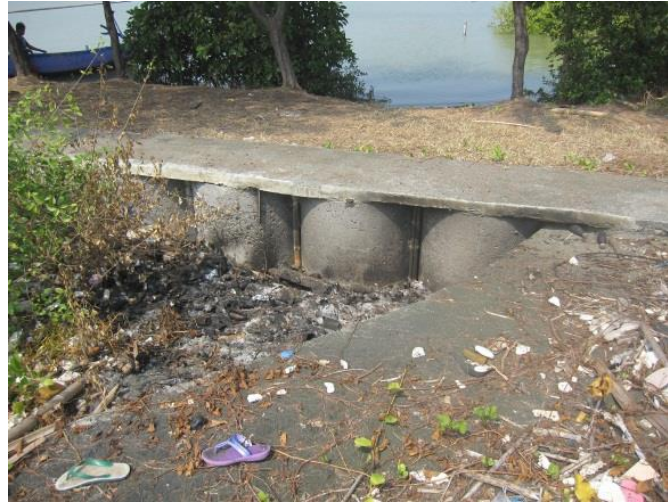

(a)

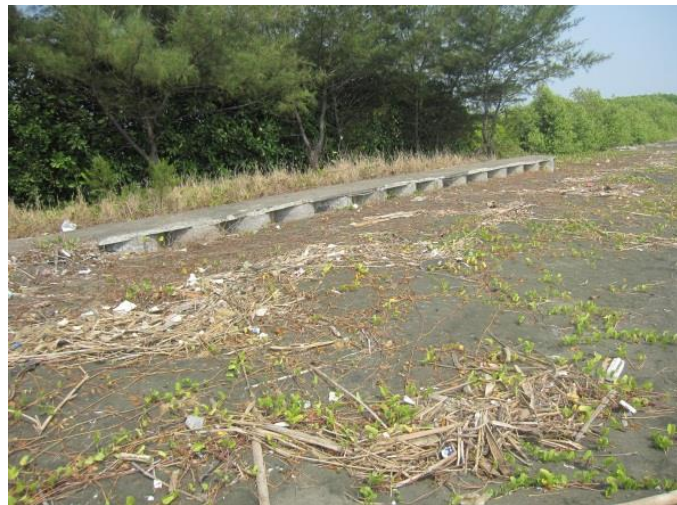

(b)

Sumber: Dokumentasi Penulis, 2018

\section{Gambar 4. APO Yang Dibangun Oleh Kelompok Biota Foundation di Pesisir Mangrove}

Secara faktual telah banyak kegiatan Biota Foundation yang memberikan sumbangsih kepada lingkungan kawasan pesisir Kelurahan Mangunharjo. Sumbangsih tersebut berasal dari dukungan berbagai kalangan seperti Direktorat Jenderal Kelautan Pesisir dan PulauPulau Kecil (KP3K), Pemerintah Provinsi Jawa Tengah (BLH, DKP, dan Dinas Kehutanan), Pemerintah Kota Semarang (Dinas Kelautan dan Perikanan, Badan Lingkungan Hidup, dan Dinas Pertanian), Djarum Foundation, dan kalangan akademisi.

\section{Lembaga Kali Santren}

Kelompok Kali Santren merupakan kelompok peduli lingkungan yang dibentuk sejak tahun 1998. Pada tahun 2011, kelompok yang diketuai oleh Ali Imron ini berganti nama menjadi Lembaga Kali Santren. Nama Kali Santren diambil dari nama sungai yang melewati wilayah Kelurahan Mangunharjo yang menjadi domisili anggota kelompoknya. Kelompok Lembaga Kali Santren merupakan perkumpulan para petani tambak udang, kerang jahe, dan bandeng.

Akivitas lingkungan yang telah dilakukan oleh Lembaga Kali Santren berupa pembibitan mangrove, penanaman mangrove, serta pendampingan penelitian. Kelompok Kali Santren aktif menanam mangrove sejak tahun 2011 yang dimulai dengan adanya program Kebun Bibit Rakyat (KBR) dari Dinas Pertanian dan Kehutanan Provinsi Jawa Tengah. Tahun 2011-2012 telah dilakukan penanaman mangrove sebanyak 50.000 bibit dari jenis Rhizopora mucronata, Rhizopora apiculata, Avicennia marina, dan Bruguera. Pada tahun-tahun berikutnya Lembaga Kali Santren semakin aktif di dalam pembibitan dan penanaman mangrove di wilayah Mangunharjo dan sekitarnya. Dari informasi Lembaga Kali Santren, pada awalnya di wilayah tersebut selain Rhizopora dan Avicennia, juga terdapat mangrove dari jenis Sonerasia, Stigi (Pemphis acidula), Lumnitzera sp, dan juga jeruju (Acanthus ilicifolius).

Pada awal tahun 2017, kelompok Kali Santren bersama dengan kelompok lingkungan yang lain di Kelurahan Mangunharjo, Kelurahan Mangkang Wetan, dan Kelurahan Mangkang Kulon telah membentuk pokdarwis yang diberi nama "Ngebruk Jaya Beach". Pokdarwis ini beranggotakan kelompok nelayan, lingkungan, petani tambak, dan pengolah hasil mangrove. Pembentukan pokdarwis tersebut merupakan pengembangan kelompok dalam memfasilitasi ekowisata mangrove bagi masyarakat yang hendak berwisata di pesisir Kelurahan Mangunharjo.

Pengembangan ekowisata mangrove tersebut akan memberikan banyak manfaat bagi masyarakat. Sebagaimana hasil studi Umam et al (2015), keberadaan ekowisata mangrove akan memberikan manfaat dari aspek sosial, ekonomi maupun agribisnis. Ditinjau dari aspek sosial, manfaatnya berupa kenyamanan untuk beraktivitas dengan adanya lingkungan yang semakin 
membaik, serta dapat meningkatkan kesejahteraan. Secara ekonomi, ekowisata menciptakan lapangan bagi masyarakat sekitarnya. Adapun manfaat dari aspek agribisnis antara lain berupa terbukanya berbagai peluang usaha seperti industri sirup dan kripik dengan bahan dasar buah mangrove.

Dalam perkembangannya, Lembaga Kali Santren telah melakukan berbagai kerja sama dengan berbagai pihak yang mendukung kegiatan-kegiatan yang dilakukan untuk perbaikan kawasan pesisir. Berbagai lembaga dan dinas yang telah mendampingi dan bekerja sama dengan Kali Santren antara lain KeSEMaT dan Fakultas Perikanan dan Kelautan Undip, Dinas Perikanan Kota Semarang dan Provinsi Jawa Tengah, Dinas Pertanian dan Kehutanan Provinsi Jawa Tengah, Lembaga Kanopi, serta lembaga-lembaga yang lain.

\section{Kelompok Mangrove Lestari}

Kelompok Mangrove Lestari yang didirikan pada tahun 2012 diketuai oleh Sururi. Kelompok ini lebih banyak bergerak pada pembibitan dan penanaman mangrove. Bibit mangrove yang dikembangbiakkan dari jenis Rhizopora sp dan Avicennia marina. Meskipun relatif baru, Kelompok Mangrove Lestari cukup dikenal berbagai instansi dan perguruan tinggi dalam melakukan pembibitan dan penanaman mangrove. Penanaman tidak hanya dilakukan di dalam tetapi juga luar wilayah Mangunharjo, seperti penanaman pada wilayah Pantai Marina Kota Semarang dan pesisir Kabupaten Rembang. Untuk program rehabilitasi kawasan pesisir, Kelompok Mangrove Lestari telah banyak melakukan kerja sama dengan Djarum Foundation dan UNDIP.

\section{Pengelolaan Lingkungan Kawasan Pesisir Berbasis Masyarakat}

Sejauh ini belum ada kelembagaan yang bersifat formal dalam pengembangan pesisir Kota Semarang. Mempertimbangkan antusias, keinginan, dan harapan masyarakat setempat, maka bentuk kelembagaan yang paling ideal adalah kelembagaan partisipatif. Pelibatan masyarakat sebagai subjek diperlukan dalam seluruh kegiatan yang berkaitan dengan pengembangan kawasan pesisir. Pembentukan kelembagaan tersebut perlu didukung dengan adanya perangkat hukum dan kebijakan yang dilandasi dengan komitmen yang kuat dari seluruh pihak (Diarto et.al, 2012).

Program Pengelolaan Lingkungan Berbasis Pemberdayaan Masyarakat (PBLPM) adalah salah satu upaya pemerintah untuk membangun kemandirian pemerintah daerah dan menumbuhkan kesadaran masyarakat dalam menanggulangi permasalahan lingkungan yang terjadi. Sesuai dengan Pasal 70 Undang-Undang Nomor 32 Tahun 2009 tentang Pengelolaan dan Perlindungan Lingkungan Hidup, masyarakat memiliki hak dan kesempatan yang sama dan seluas-luasnya untuk berperan aktif dalam perlindungan dan pengelolaan lingkungan hidup. Peran masyarakat dilakukan untuk meningkatkan kepedulian dalam perlindungan dan pengelolaan lingkungan hidup. Namun, masih diperlukan pendampingan yang lebih intensif dari berbagai sektor terhadap kelompok-kelompok masyarakat untuk mendukung perbaikan kawasan pesisir. Pelibatan di dalam perencanaan penanaman jenis dan kerapatan mangrove sangat menentukan keberhasilan program perbaikan kawasan pesisir Kota Semarang.

Pengelolaan lingkungan di pesisir cukup dinamis mengingat keberadaan kelompokkelompok lingkungan yang saling bersinergi memperbaiki lingkungan. Penanaman mangrove oleh kelompok lingkungan dilakukan di lokasi sekitar tambak ikan/udang milik kelompok petani tambak. Namun, belum ada sosialisasi, pendampingan, serta percontohan terkait pola penanaman yang dapat memberi keuntungan bagi semua pihak tanpa merusak lingkungan (Martuti et al., 2016).

Revitalisasi dengan penanaman mangrove di dalam tambak dapat dilakukan dengan kerja sama yang baik antara petani tambak dan kelompok masyarakat peduli lingkungan. Revitalisasi dapat pula dilakukan bersama-sama dengan dinas terkait, karena adanya program penanaman yang dilakukan oleh beberapa dinas. Selain itu, adanya sosialisasi dan pembinaan terhadap masyarakat khususnya petani tambak mengenai peran mangrove diperlukan bagi kelestarian lingkungan pesisir. Program wanamina merupakan salah satu hal 


\section{Peran Kelompok Masyarakat dalam Rehabilitasi Ekosistem Mangrove di Pesisir Kota Semarang}

yang dapat dilakukan untuk mendukung pengelolaan mangrove yang baik dengan tetap menjaga keutuhan dan kelestarian lingkungan. Adanya wanamina dapat memberikan manfaat ekonomi dan sosial yang besar kepada masyarakat secara berkelanjutan. Budi daya ikan dengan sistem wanamina sesuai dengan Pasal 3 Undang-Undang Nomor 5 Tahun 1990 tentang Konservasi Sumber Daya Alam Hayati dan Ekosistemnya. Konservasi sumber daya alam hayati dan ekosistemnya bertujuan mengusahakan terwujudnya kelestarian sumber daya alam hayati serta keseimbangan ekosistemnya, sehingga dapat lebih mendukung upaya peningkatan kesejahteraan masyarakat dan mutu kehidupan manusia.

Kelembagaan sosial diperlukan untuk meningkatkan peran masyarakat dalam perlindungan wilayah dan sumber daya alam. Tujuannya adalah untuk mendorong peranan masyarakat secara bersama-sama. Semangat kebersamaan tersebut akan mendorong upaya pemberdayaan masyarakat untuk melindungi wilayahnya dari kerusakan yang dapat mengancam perekonomian. Adanya pemberdayaan masyarakat melalui pengembangan lembaga sosial diharapkan untuk memperkuat posisi masyarakat dalam menjalankan fungsi manajemen kawasan pesisir. Fitriansah (2012) menyampaikan bahwa program pengelolaan lingkungan berbasis masyarakat dapat berperan sebagai dasar bagi pengembangan ekonomi kawasan pesisir. Melalui pelibatan pemerintah daerah, masyarakat, dan pemangku kepentingan lainnya program tersebut diharapkan dapat memberikan dampak lanjutan terutama dalam pengembangan ekonomi di kawasan pesisir melalui sistem pembelajaran sederhana dalam membuat perencanaan dan menata sendiri permukiman dan lingkungannya. Program pengelolaan lingkungan berbasis masyarakat dapat berperan sebagai dasar bagi pengembangan ekonomi kawasan pesisir. Proses pembelajaran tersebut dimulai dari proses perencanaan ruang kawasan permukiman oleh masyarakat dengan didampingi oleh pemerintah daerah dan tenaga pendamping.

Pelibatan masyarakat bersama-sama dengan Organisasi Pemerintah Daerah (OPD) di dalam pengelolaan kawasan pesisir Kota Semarang sesuai dengan Peraturan Daerah Kota Semarang Nomor 14 Tahun 2011 tentang Rencana Tata Ruang Wilayah Kota Semarang 2011-2031. Rencana strategis kawasan pesisir Kota Semarang tersebut memberikan arah kebijakan kepada OPD dan pemangku kepentingan dalam pengelolaan kawasan pesisir dan melaksanakan program-program pembangunan di kawasan pesisir, terkait dengan pencapaian tujuan ekologi, peningkatan ekonomi, pengembangan sosial-budaya dan kelembagaan masyarakat pesisir.

Salah satu inisiatif yang dilakukan Pemerintah Kota Semarang dalam menjaga lingkungan mangrove berbasis masyarakat yaitu melalui pembentukan Kelompok Kerja Mangrove Kota Semarang (KKMKS) melalui Surat Keterangan Walikota Semarang Nomor 0504/466 tanggal 22 Desember 2010. KKMKS merupakan sebuah forum silaturahmi dan kerja sama para penggiat mangrove di Kota Semarang yang beranggotakan berbagai lapisan masyarakat. Anggota KKMKS membentuk sebuah jaringan mangrove di Kota Semarang yang berfungsi mengoordinasikan program dan proyek mangrove yang sudah, sedang, dan akan dijalankan. Tujuan pembentukan KKMKS adalah untuk mengendalikan kerusakan ekosistem mangrove melalui penentuan langkah-langkah strategis yang dapat menjamin terselenggaranya perlindungan, pelestarian, dan pemanfaatan ekosistem mangrove sebagai sumber daya di kawasan pesisir, sistem penyangga kehidupan, dan kekayaan alam yang bernilai tinggi.

Kegiatan konservasi dengan pelibatan masyarakat merupakan kunci keberhasilan dalam kegiatan pemulihan dan pengelolaan pelestarian mangrove kawasan pesisir (Wardhani, 2011). Upaya tersebut harus disertai dengan peningkatan kesejahteraan masyarakat berbasis potensi lokal. Kegiatan dilakukan untuk mencapai pembangunan pesisir yang berkelanjutan, sehingga dapat memberikan manfaat ekonomi yang optimal bagi masyarakat dan pemerintah daerah, sekaligus mempertahankan kualitas ekosistem mangrove sebagai sistem penyangga kehidupan. 
Pengelolaan kawasan pesisir secara terpadu merupakan upaya dari berbagai instansi lintas-sektoral antara pemerintah, komunitas, ilmu pengetahuan, manajemen, kepentingan sektoral dan kepentingan masyarakat dalam persiapan dan perencanaan secara terpadu guna perlindungan dan pengembangan ekosistem pesisir beserta sumber dayanya. Adanya pengelolaan kawasan pesisir tersebut bertujuan untuk meningkatkan kualitas hidup dari suatu komunitas masyarakat yang menggantungkan hidupnya dari sumber daya yang terkandung di kawasan pesisir, sekaligus menjaga keanekaragaman hayati dan produktivitas dari ekosistem pesisir.

\section{Kesimpulan}

Berdasarkan kajian tersebut maka dapat disimpulkan bahwa peran masyarakat dalam upaya rehabilitasi kerusakan pesisir terkait ekosistem mengrove sudah relatif bagus. Pada umumnya mereka sadar bahwa kerusakan yang terjadi perlu segera ditanggulangi, karena kerusakan terhadap ekosistem mangrove dapat mengakibatkan degradasi lingkungan yang berdampak pada penurunan kualitas hidup mereka. Masyarakat memiliki peranan penting dalam pengelolaan dan perbaikan kualitas pesisir di Kota Semarang. Hal tersebut terjadi karena masyarakat setiap hari berinteraksi dengan lingkungan, sehingga pengelolaannya akan lebih efektif dan efisien. Berbagai kegiatan yang telah dilakukan oleh kelompok masyarakat dalam mengelola dan rehabilitasi kualitas pesisir khususnya di Kelurahan Mangunharjo dan Dukuh Tapak Kelurahan Tugurejo antara lain:

1. Pembuatan APO dengan bahan ban bekas yang selanjutnya diisi lumpur di bagian dalamnya untuk mencegah meluasnya abrasi di pesisir Dukuh Tapak Kelurahan Tugurejo;

2. Penanaman mangrove, pembuatan sabuk pantai atau breakwater dari beton, dan penelitian serta studi lingkungan pesisir yang dilakukan oleh Biota Foundation di Kelurahan Mangunharjo;

3. Pembibitan dan penanaman mangrove serta pendampingan kegiatan penelitian yang dilakukan oleh para petani tambak udang, kerang jahe dan bandeng yang tergabung dalam Kelompok Kali Santren yang dilakukan di Kelurahan Mangunharjo; dan

4. Pembibitan dan penanaman mangrove khususnya untuk jenis Rhizopora $s p$ dan Marina yang dilakukan oleh Kelompok Mangrove Lestari bekerja sama dengan Djarum Fondation dan Undip.

Selanjutnya, pengelolaan lingkungan pesisir berkelanjutan memerlukan kelembagaan partisipatif yang melibatkan berbagai pihak dengan menjadikan masyarakat sebagai subjek utama. Kegiatan tersebut membutuhkan koordinasi dari Pemerintah Kota Semarang melalui instansi yang mempunyai kewenangan, sehingga dapat memberikan dampak yang lebih baik bagi kelestarian kawasan pesisir secara menyeluruh.

\section{Ucapan Terima Kasih}

Penelitian tentang peran kelompok masyarakat di kawasan pesisir Kota Semarang ini terlaksana atas hibah penelitian dari DRPM Ristekdikti pada skema Penelitian Terapan Unggulan Perguruan Tinggi (PTUPT) pendanaan tahun 2017-2018. Oleh karena itu, penulis mengucapkan terima kasih kepada DRPM Ristekdikti atas kesempatan yang telah diberikan sehingga kegiatan penelitian dapat berjalan dengan baik. Semoga apa yang kita lakukan dapat bermanfaat untuk masyarakat yang membutuhkan.

\section{Daftar Pustaka}

Ambariyanto, \& Sugianto, D. N. (2012). Kajian pengembangan desa pesisir tangguh di kota semarang. Riptek, 


\section{Peran Kelompok Masyarakat dalam Rehabilitasi Ekosistem Mangrove di Pesisir Kota Semarang}

6(II), 29-38. $\quad$ Retrieved from http://bappeda.semarangkota.go.id/v2/wpcontent/uploads/2013/12/3.DESA-PESISIR-TANGGUH_2-kolom_nanik.pdf.

Badan Pusat Statistik (BPS) Kota Semarang. (2017). Kota Semarang dalam angka 2017. Semarang: Badan Pusat Statistik Kota Semarang.

Basyuni, M., Bimantara, Y., Selamet, B., \& Thoha, A. S. (2016). Identifikasi potensi dan strategi pengembangan ekowisata mangrove di Desa Lubuk Kertang, Kecamatan Brandan Barat, Kabupaten Langkat Sumatera Utara. Abdimas Talenta, 1(1), 31-38.

Baxter, P., \& Jack, S. (2008). Qualitative case study methodology: Study design and implementation for novice researchers. The Qualitative Report, 13(4), 544-559. doi:citeulike-article-id:6670384.

Diarto, Hendrarto, B., \& Suryoko. (2012). Silvofishery Developing Strategy in Mangrove Forest Area of Tugurejo in Semarang. In Prosiding Seminar Nasional Pengelolaan Sumberdaya Alam dan Lingkungan (pp. 47-59). Retrieved from http://eprints.undip.ac.id/37604/.

Dinas Kelautan dan Perikanan Kota Semarang. (2015). Pemetaan potensi, kerusakan dan model rehabilitasi Kawasan Pesisir Kota Semarang. Semarang.

Fitriansah, H. (2012). Keberlanjutan pengelolaan lingkungan pesisir melalui pemberdayaan masyarakat di Desa Kwala Lama Kabupaten Serdang Bedagai. Jurnal Pembangunan Wilayah \& Kota, 8(4), 360-370. Retrieved from https://ejournal.undip.ac.id/index.php/pwk/article/view/6492/5357.

Halibas, A. S., Sibayan, R. O., \& Maata, R. L. R. (2017). The penta helix model of innovation in Oman: An hei perspective. Interdisciplinary Journal of Information, Knowledge, and Management, 12, 159-172. doi:10.28945/3735.

Hartati, R., Pribadi, R., Astuti, R. W., Yesiana, R., \& Hidayati, I. Y. (2016). Kajian pengamanan dan perlindungan pantai di wilayah pesisir Kecamatan Tugu dan Genuk, Kota Semarang. Jurnal Kelautan Tropis, 19(2), 95100. doi:10.14710/jkt.v19i2.823.

Ichsan, I., \& Suleman, A. H. (2018). Analisis perencanaan break water dalam penanganan sedimentasi pantai di Desa Botubarani. Gorontalo Journal of Infrastructure \& Science Engineering, 1(1), 82-93. Retrieved from http://jurnal.unigo.ac.id/index.php/gjise/article/download/158/154.

Macintosh, D. J., \& Ashton, E. C. (2002). A review of mangrove biodiversity conservation and management.

Martuti, N. (2013). Keanekaragaman mangrove di wilayah Tapak, Tugurejo, Semarang. Jurnal MIPA, 36(2), 123130. Retrieved from https://journal.unnes.ac.id/nju/index.php/JM/article/view/2971/0.

Martuti, N. K. T., Setyowati, D. L., Nugraha, S. B., \& Mutiatari, D. P. (2017). Carbon stock potency of mangrove ecosystem at Tapak Sub-village, Semarang, Indonesia. AACL Bioflux, 196), 1524-1533. Retrieved from http://www.bioflux.com.ro/docs/2017.1524-1533.pdf.

Martuti, N. T. K., Widianarko, B., \& Yulianto, B. (2016). Eliminasi logam Cu oleh serasah Avicennia marina di lingkungan tambak bandeng wilayah Tapak tugurejo, Semarang. Jurnal Manusia Dan Lingkungan, 23(3), 304-309. doi:10.22146/jml.18800.

Mercy Corps Indonesia. (2016). Final narrative report: Enhancing coastal community resilience by strengthening mangrove ecosystem services and developing sustainable livelihoods in Semarang City. Semarang.

Miles, M. B., Huberman, A. M., \& Saldana, J. (2014). Qualitative data analysis: A methods sourcebook. Thousand Oaks, CA: Sage.

Nazir, M. (2011). Metode penelitian. Jakarta: Ghalia Indonesia.

Raharjo, P., Setiady, D., Zallesa, S., \& Putri, E. (2015). Identifikasi kerusakan pesisir akibat konversi hutan bakau (mangrove) menjadi lahan tambak di Kawasan Pesisir Kabupaten Cirebon. Jurnal Geologi Kelautan, 13(1), $9-24$.

Sakuntaladewi, N., \& Sylviani, S. (2014). Kerentanan dan upaya adaptasi masyarakat pesisir terhadap perubahan iklim. Jurnal Penelitian Sosial Dan Ekonomi Kehutanan, 11(4), 281-293. Retrieved from http://ejournal.forda-mof.org/latihan/index.php/JPSE/article/view/699.

Setyawan, A. D., \& Winarno, K. (2006). Pemanfaatan langsung ekosistem mangrove di Jawa Tengah dan penggunaan lahan di sekitarnya; kerusakan dan upaya restorasinya. Biodiversitas, Journal of Biological Diversity, 73), 282-291. doi:10.13057/biodiv/d070318.

Soesilowati, E., Kariada, N., \& Margunani, M. (2017). Model for empowering farmers at dry land through quadruple helix approach. Journal of Arts \& Humanities, 64), 1-9. doi:10.18533/journal.v6i4.1131.

Umam, K., Sudiyarto, S., \& Winarno, S. T. (2015). Strategi pengembangan ekowisata mangrove Wonorejo 
Surabaya. AGRARIS: Journal of Agribusiness and Rural Development Research, 1(1), 38-42. doi:10.18196/agr.116.

Wardhani, M. K. (2011). Kawasan konservasi mangrove: Suatu potensi ekowisata. Jurnal Kelautan, 4(1), 60-76. Retrieved from journal.trunojoyo.ac.id/jurnalkelautan/article/view/891/784.

Widayatun. (2011). Peran masyarakat dalam pelestarian terumbu karang dan dampaknya terhadap peningkatan kesejahteraan. Jurnal Kependudukan Indonesia, VI(2), 1-19. Retrieved from http://ejurnal.kependudukan.lipi.go.id/index.php/jki/article/download/91/137.

Wijayanti, W. P., \& Pratomo, R. A. (2016). Adaptation of social-economic livelihoods in coastal community: The case of Mangunharjo Sub-district, Semarang City. In Procedia - Social and Behavioral Sciences (Vol. 227, pp. 477-484). doi:10.1016/j.sbspro.2016.06.103.

Yulistiyanto, B. (2009). Mangrove dengan alat pemecah ombak (APO) sebagai perlindungan garis pantai. In Seminar Nasional Manajemen Sumberdaya Air Partisipatif Guna Mengantisipasi Dampak Perubahan Iklim Global. 